\title{
Amino acid needs and protein scoring patterns
}

\author{
BY PETER J. REEDS \\ USDA/ARS Children's Nutrition Research Center, Department of Pediatrics, Baylor College of \\ Medicine, 1100 Bates Street, Houston, Texas 77030, USA
}

Human amino acid requirements have been the subject of intense debate for the last 3 years (Young, 1987; Beaton \& Chery, 1988; Millward \& Rivers, 1988; Young \& Pellett, 1988; Millward et al. 1989; Young et al. 1989) and recent publications (Fuller \& Wang, 1988: Fuller et al. 1989) reappraised the amino acid pattern (Agricultural Research Council, 1981) that optimizes growth in the pig. The present paper also addresses amino acid patterns, as opposed to absolute quantities of protein or nitrogen, in an effort to clarify some aspects of the various approaches to the formulation of dietary recommendations. The purpose of the present paper is not to present yet another 'amino acid pattern' for discussion, nor to support one view over another, but instead to promote some degree of reconciliation between opposing views on this subject.

\section{ALLOWANCES, NEEDS, AND REQUIREMENTS}

The Food and Agriculture Organization/World Health Organization/United Nations University (1985) conclusions regarding dietary amino acids were presented as 'recommended allowances' and not 'requirements', the two are often confused with one another. As Fuller \& Wang (1988) point out, recommended allowances are reflections of needs, as set by the physiological and metabolic state of the individual, but do not convey direct information about the biology of protein and amino acid metabolism and deposition. Thus, dietary allowances will always exceed needs by at least the degree to which inefficiencies are introduced by digestion, absorption, and the metabolic transformations that accompany the ultimate utilization of dietary amino acids.

\section{OPERATIONAL AND FACTORIAL ESTIMATES}

Dietary allowances have been defined generally by two approaches, which can be termed operational and factorial. Operational methods define the amounts of different amino acids that have to be ingested to maintain some outcome variable within normal or desirable limits. As such, they are concerned predominately with practical considerations and have proved particularly effective in the formulation of recommendations for the growth of farm and laboratory animals.

The usefulness of the approach, however, depends ultimately on the choice of outcome, the limits that are chosen, and the particular experimental circumstances of the estimation. In agricultural studies, the chosen outcome and its limits generally are set by the economics of animal production so that these constraints may be relatively unimportant to the general applicability of the recommendations that ensue. Even so, the choice of the output variable (e.g. weight-gain, amino acid concentrations, $N$ excretion, etc.) may have an important bearing on the practical simplicity of the measurements and the applicability of the results to other circumstances. As discussed 
Table 1. Comparison of the pattern of amino acids in body protein with the pattern of dietary amino acids ( $\mathrm{g}$ amino acid/l6 $\mathrm{g}$ nitrogen) that optimizes protein utilization for growth

\begin{tabular}{|c|c|c|c|}
\hline & $\begin{array}{c}\text { Body } \\
\text { protein* }\end{array}$ & $\begin{array}{c}\text { Dietary } \\
\text { pattern' }\end{array}$ & Ratio \\
\hline Leucine & 6.9 & $7 \cdot 8$ & $1 \cdot 13$ \\
\hline Isoleucine & $4 \cdot 1$ & $4 \cdot 3$ & 1.05 \\
\hline Valine & $5 \cdot 0$ & $5 \cdot 2$ & 1.04 \\
\hline Lysine & 7.8 & $6 \cdot 8$ & 0.87 \\
\hline Threonine & $4 \cdot 2$ & 4.7 & $1 \cdot 11$ \\
\hline Aromatic & $7 \cdot 6$ & 8.4 & $1 \cdot 10$ \\
\hline Sulphur & $3 \cdot 4$ & $3 \cdot 6$ & $1 \cdot 06$ \\
\hline NEAA:EAA' & $52: 48$ & $54: 46$ & 1.27 \\
\hline Mean & & & $1 \cdot 08$ \\
\hline SD & & & $0 \cdot 10$ \\
\hline
\end{tabular}

NEAA:EAA, non-essential amino acids:essential amino acids.

* Mean composition of rat, pig and cattle (Reeds, 1987).

† As defined by Fuller \& Wang (1988) for the growing pig.

later, the choice may also have a substantial effect on the pattern of dietary amino acids that is ultimately defined as optimal.

In human nutrition studies, the problem of a choice of outcome can be serious. Choices may be between poorly defined terms such as 'normal', 'optimal', 'maximal' and 'well-being'. For example, one basis of the criticism of the FAO/WHO/UNU (1985) report levelled by Beaton \& Chery (1988) in regard to the dietary protein allowances for infants beyond 4 months of age, was the assumption that weight gain and $\mathrm{N}$ retention of breast-fed infants were adequate or normal, though infants are capable of maintaining a rate of $\mathrm{N}$ retention substantially greater than normal.

In studies of adults, Young et al. (1989) and Millward \& Rivers (1988) have emphasized that the intake and perhaps the pattern of amino acids necessary to maintain protein balance are not necessarily the same as those associated with maximum rates of protein turnover. Recommendations based on the former criterion will differ from those based on the latter, even though each is readily defensible on either practical or metabolic grounds. To a great extent, personal preference may determine the criteria regarded as appropriate. In human nutrition, the problems are exacerbated by the practical difficulties inherent in the performance of large controlled feeding trials or metabolic measurements that are required to formulate generally applicable recommendations.

Ideally, factorial methods are based on an understanding of the underlying biology of amino acid disposal. Thus, they attempt both to quantify the rates of processes in which amino acids are used and to ascribe to each a physiological importance. They thus seek to create an ideal pattern that supports all (or a subset) of the identifiable process at given rates. It is critical to recognize that this approach defines an absolute minimum or obligatory need which, by definition, will always be less than the quantity that must be supplied in the diet. 
Table 2. Amino acid composition ( $\mathrm{g}$ amino acid/16 $\mathrm{g}$ nitrogen) of the human fetus and of mixed human milk proteins

\begin{tabular}{|c|c|c|c|}
\hline & $\begin{array}{l}\text { Human } \\
\text { fetus* }\end{array}$ & $\begin{array}{c}\text { Milk } \\
\text { proteins }{ }^{\dagger}\end{array}$ & Ratio \\
\hline Leucine & 83 & 101 & 1.22 \\
\hline Isoleucine & 37 & 55 & 1.49 \\
\hline Valine & 47 & 61 & $1 \cdot 30$ \\
\hline Lysine & 72 & 74 & $1 \cdot 03$ \\
\hline Threoninc & 46 & 50 & 1.09 \\
\hline Sulphur & 39 & 36 & 0.92 \\
\hline Aromatic & 51 & 91 & 1.78 \\
\hline Glycine & 85 & 24 & 0.28 \\
\hline NEAA:EAA & $58: 42$ & $54: 46$ & 0.85 \\
\hline Mean & & & $1 \cdot 10$ \\
\hline SD & & & 0.40 \\
\hline
\end{tabular}

NEAA:EAA, non-essential amino acids:essential amino acids.

* Composition of the human fetus (Widdowson ef al. 1979).

$\dagger$ Milk composition as summarized by Reeds (1988).

There are two main problems to be solved: (1) the identification of the processes that are both physiologically and quantitatively important, and the definition of the appropriate amino acid patterns to support then in order to define the obligatory need, and (2) the conversion of this into a dietary recommendation.

One characteristic of the FAO/WHO/UNU (1985) studies, and recent papers on this subject (e.g. Millward \& Rivers, 1988; Young \& Pellett, 1988), is the attempt to combine the operational and functional methods. In formulating recommended amino acid allowances for infants, the FAO/WHO/UNU (1985) report used the factorial approach to define the mixture of amino acids. To define desirable intakes of protein this result was combined with an operational assessment (e.g. Fomon et al. 1971) of the relationship between $\mathrm{N}$ intake and balance in infants.

Ultimately, of course, both the operational and the functional approaches should give similar estimates of amino acid patterns in the dietary allowance. There has been general agreement as far as estimates for growth are concerned (Table 1). In other circumstances, however, the attempt to reconcile the two approaches has proved difficult. This is especially true of the optimal amino acid pattern to support $\mathrm{N}$ equilibrium. This lack of success poses important questions as to both the basis of amino acid needs and the general applicability of operational assessments of dietary allowances.

\section{METABOLIC PATHWAYS CONTRIBUTING TO AMINO ACID NEEDS}

In the simplest linear factorial model, the minimal amino acid needs are partitioned between net protein production and maintenance. The former considers the amino acid composition of protein deposition in the body during growth, protein deposition in mother and fetus during pregnancy, and the secretion of protein, amino acids and, perhaps, non-protein- $\mathrm{N}$ in milk. Information is available that enables the prediction of 
the appropriate amino acid patterns, but as far as man is concerned extensive quantification of amino acid patterns is available only for mixed milk proteins and the near-term fetus (Table 2).

There are, moreover, four areas in which problems of understanding exist: (1) non-protein pathways of amino acid use, (2) intermediary metabolism of amino acids, (3) the role of amino acids in the regulation of protein turnover and deposition, and (4) the impact of gastrointestinal prorein metabolism on amino acid needs.

Non-protein pathways of amino acid use. Although information on protein and amino acid allowances has been based on $\mathrm{N}$ balance, it is not strictly correct to equate $\mathrm{N}$ balance with protein balance. The diet, especially human milk (see Fomon et al. 1971), contains significant amounts of non-protein- $\mathrm{N}$ and some amino acids act as important precursors for the synthesis of nitrogenous compounds whose retention is not necessarily linked to protein deposition at the mechanistic level (Table 3). Some of these end-products (e.g. haem and creatine) are not recycled and represent a continual drain on the utilization of the precursor amino acids, notably glycine and methionine. For example, adult man may require $1 \mathrm{~g}$ glycine/d to support the sum of creatine and haem synthesis, although when consuming a protein-free diet, adult man mobilizes at most $1.5 \mathrm{~g}$ glycine from body stores. Furthermore, creatine synthesis results in the retention of glycine- $N$, but not glycine-carbon. Conversely, methionine utilization in methyl group metabolism is part of methionine need, but does not conserve methionine- $\mathrm{N}$.

Intermediary amino acid metabolism and the concept of non-essential amino acids. Amino groups are now understood not to be transferred freely between all amino acids (Alqvist, 1951; Jackson \& Golden, 1980; Matthews et al. 1981). A classification of amino acids into three groups is now becoming accepted (Jackson \& Golden, 1980; Young, 1987).

(1) Essential, in the sense that specific parts of their structures can be obtained only from the diet.

(2) Non-essential, in the sense that they can be synthesized from Kreb's cycle intermediates and free amino groups (either by transamination or reductive amination).

(3) Conditionally essential, in the sense that they require preformed $\mathrm{C}$ side chains and substituent groups derived from other amino acids. For example, glycine, serine, and cysteine may well function as a group in which a limited supply of any one could inhibit the ability of the organism to synthesize the others, and render them limiting to overall amino acid utilization.

In addition, the maintenance of other $\mathrm{N}$ cycles, chiefly the glutamine cycle (Rennie et al. 1986), can also influence the needs for those amino acids that donate $\mathrm{N}$ to the cycle.

These metabolic considerations have the potential to influence the interpretation of operational assessments under three circumstances of amino acid limitation.

(1) A primary limitation by an essential amino acid. This will automatically limit the utilization of all other amino acids and lead to equal losses of their $\mathrm{C}$ and $\mathrm{N}$.

(2) A limitation by non-essential amino acids. In this case the $\mathrm{N}$, but not the $\mathrm{C}$, of essential amino acids may be retained.

(3) Limitation by a conditionally essential amino acid. This will lead to a differential retention of $\mathrm{C}$ and $\mathrm{N}$ from the specific donor amino acids.

Amino acid regulation of protein turnover. Both Young et al. (1989) and Millward et al. (1989) have addressed the issue of amino acid regulation of protein turnover. Both groups have emphasized that one aspect of amino acid needs may be the maintenance of 
Table 3. Some non-protein pathways of amino acid utilization

\begin{tabular}{|c|c|}
\hline Amino acid & Pathway \\
\hline Methionine & $\begin{array}{l}\text { Methylation reactions } \\
\text { Creatine } \\
\text { Choline }\end{array}$ \\
\hline Cysteine & $\begin{array}{l}\text { Glutathione } \\
\text { Taurine }\end{array}$ \\
\hline Tyrosine & Neurotransmitters \\
\hline Glutamate & Neurotransmitters \\
\hline Lysine & Carnitine \\
\hline Glycine & $\begin{array}{l}\text { Nucleic acid bases } \\
\text { Haem } \\
\text { Creatine }\end{array}$ \\
\hline
\end{tabular}

protein turnover above a certain limit, regardless of whether net protein retention occurs. Although Millward et al. (1990) discuss the potential for amino acid regulation of protein turnover in greater detail in this symposium, some questions are worthy of re-emphasis.

Can the rate of supply of any amino acid regulate protein turnover in this fashion or is regulation of protein turnover restricted to a limited number?

The former possibility would help explain how the organism is apparently able to transduce the increased supply of any limiting amino acid (Fuller et al. 1987; Fuller \& Wang, 1988) into an appropriate metabolic response. The latter possibility, however. would imply that some amino acids may be used less efficiently than others when their regulatory role results in some inevitable catabolism (Millward et al. 1989).

Does the sensitivity of the regulatory system vary with physiological state? For example, does an increase in sensitivity explain the increase in the efficiency of dietary protein utilization that apparently occurs in malnourished individuals (see Golden et al. 1977; Hovell et al. 1987). Alternatively, does a decrease in sensitivity occur when protein intake approaches a value that will support the genetically determined maximum rate of protein deposition?

Role of gastrointestinal protein flow. In all the current models of amino acid requirements and allowances, faecal $\mathrm{N}$ losses are explicitly treated as components of dietary digestibility. This designation occurs because $\mathrm{N}$ fixation by the gut flora results in a pattern of amino acids in the faeces that bears little relationship to the pattern of amino acids that supplies this $\mathrm{N}$ (Mason \& Palmer, 1973). The treatment, however, is an over simplification.

Substantial quantities of protein are known to be secreted into the gastrointestinal tract (Low, 1980; Rerat et al. 1988; de Lange et al. 1989a,b; Table 4). The rate of secretion is influenced by the diet and only a proportion of this loss is recycled in the small intestine, i.e. in a form that is readily available for protein deposition. Studies using prolonged intravenous infusion of stable isotopically labelled amino acids (de Lange et al. 1990) suggest that even with conventional diets, a very high proportion of the protein reaching the terminal ileum is of endogenous origin. When no protein is supplied in the diet, all faecal losses of $\mathrm{N}$ are ultimately derived from body protein. From the 
Table 4. Rates of protein flow to the terminal ileum of growing pigs receiving various diets

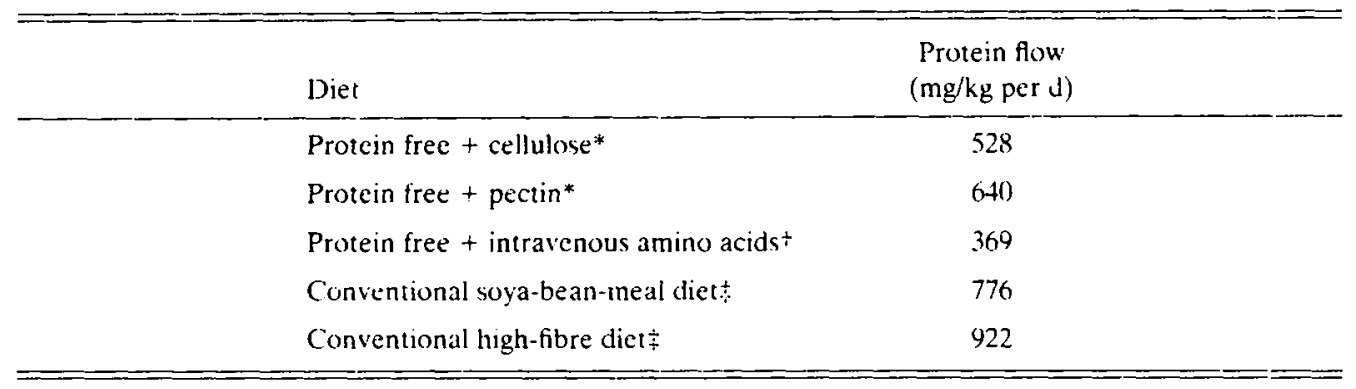

* de Lange et al. (1989a).

$\div$ de Lange et al. (1989 b).

$\doteqdot$ de Lange el al. (1990).

Table 5. A comparison of the amino acid composition ( $g$ amino acid/l6 g nitrogen) of ileal chyme protein in pigs consuming no dietary protein with the pattern of dietary amino acids that optimizes protein use close to $N$ equilibrium

\begin{tabular}{llcc}
\hline $\begin{array}{c}\text { Ileal chyme } \\
\text { protcin } \\
\text { composition }\end{array}$ & $\begin{array}{c}\text { Maintenance } \\
\text { amino acid } \\
\text { pattern }\end{array}$ & Ratio \\
\hline Leucine & 3.4 & 1.7 & 0.50 \\
Isoleucine & 2.5 & 1.1 & 0.44 \\
Valine & 3.6 & 4.9 & 1.36 \\
Lysinc & 4.4 & 2.4 & 0.54 \\
Threonine & 5.9 & 4.7 & 0.80 \\
Sulphur & 4.2 & 3.6 & 0.86 \\
Aromatic & 6.7 & 3.0 & 0.44 \\
NEAA:EAA & 70.30 & 80.20 & 1.71 \\
Mean & & & 0.73 \\
SD & & 0.32 \\
\hline
\end{tabular}

NEAA:EAA, non-essential amino acids:essential amino acids.

* From de Lange et al. (1989b).

$\leftarrow$ From Fuller \& Wang (1988) and Fuller et al. (1989).

perspective of the formulation of amino acid requirement patterns, these considerations raise three points: first, aside from the intermediary metabolic considerations discussed earlier, in a factorial treatment, the pattern of amino acid need is set by that of net amino acid utilization for protein synthesis and other pathways (Table 3 ). When $\mathrm{N}$ balance is negative or zero, intestinal protein loss is, in effect, a major route of protein deposition, in this case to the outside world.

Second, continued secretion is a necessary accompaniment of the maintenance of digestive function and protein 'loss' by this route, and it is probably increased (Table 4) when dietary protein is supplied.

Third, the amino acid composition of endogenous secretions that escape digestion in the small intestine is distinctly different from that deposited in the body (Table 5). 
Specifically, the secretions have a high non-essential:essential ratio $(2 \cdot 3: 1 \mathrm{cf}$. body protein 1:1) and are particularly rich in threonine and cysteine.

Thus, it is perhaps no coincidence that the addition of cysteine, methionine, and threonine to protein-free diets significantly reduces urinary N loss (Yoshida \& Moritoki, 1974). This suggests that continuing protein loss via the intestine is of considerable significance to the amino acid economy if protein is restricted. Young et al. (1989) have noted that the subjects of their experiments on threonine oxidation apparently remained in positive threonine balance until their intakes of threonine were very low. This finding would be consistent with threonine loss in non-recycled intestinal secretions. Finally, in studies of pigs (Table 5), the pattern of essential amino acids and the high nonessential:essential ratio in intestinal secretions is similar, although not identical, to the pattern that optimizes dietary $\mathrm{N}$ utilization at $\mathrm{N}$ equilibrium (Fuller \& Wang, 1988). 1 would argue, therefore, that maintenance amino acid needs may be driven in large part by a continuing loss of protein in the gut. If so, a supply of sulphur-containing and non-essential amino acids is the critical factor in developing amino acid scores for the adult.

Does this hypothesis resolve the current controversy? We know that when no protein is supplied in the diet, the only available source of amino acids to replace the loss is body protein itself. In this circumstance, the $\mathrm{C}$ of amino acids will be catabolized in a pattern that represents the difference between that of the supply (body protein) and that of 'deposition' (integumental, intestinal and non-protein pathways). The oxidative pattern at zero protein intake will be rich in $\mathrm{C}$ from essential amino acids. Their $\mathrm{N}$ may be conserved to some degree in the synthesis of the non-essential acids used in the pathways of amino acid disposal in intestinal protein loss and non-protein pathways. In addition, there is a negative correlation between urinary and faecal $N$ loss (Millward et al. 1989) when no protein is consumed.

The changes that occur, however, between basal (i.e. protein-free state) and $\mathrm{N}$ equilibria will probably be more complex. One outcome of the complexity will be a variation in the definition of the pattern of dietary amino acids that restores $N$ equilibrium. The variation is largely determined by the method used in the assessment. Thus, studies that use diets rich in non-essential amino acids measure the pattern of essential amino acids that leave the small intestine. Given the specific pattern of these losses, an assessment of $\mathrm{N}$ balance with proteins that are of 'good' quality investigates a circumstance in which the excretion of $\mathrm{N}$ derived from essential amino acids is minimized, because a portion passes into non-essential amino acid utilization. On the other hand, assessments of $\mathrm{C}$ catabolism will measure a pattern of loss that, in part, reflects the degree to which each essential amino acid contributes to non-essential amino acid synthesis. Both techniques measure requirements, but from slightly different perspectives: $\mathrm{N}$ metabolism of amino acids is the primary consideration in one, and $\mathrm{C}$ metabolism of amino acids in the other.

These points bring us full circle to the central question addressed by any exercise in the definition of nutrient requirements. What is their purpose?

To summarize, amino acids are needed to support net protein deposition (including losses of endogenous origin to the faeces) and synthesis of specific non-protein products; the pattern of this need varies with physiological and nutritional states and probably with other aspects (e.g. non-protein energy intake) of diet composition. Amino acids also regulate the very processes that result in protein deposition. The hypothesis of Millward 
\& Rivers (1988) is only now becoming accepted and its quantitative significance has not been established in any detail. The regulatory pattern, however, may well be different from the 'growth' and 'maintenance' patterns, and thereby influence the efficiency with which dietary protein is utilized. Despite the usefulness of defining universal dietary recommendations, such a goal may not be attainable at present, because as new information becomes available, we must consider new pathways that are not necessarily linked to accretion of the body mass but which nevertheless consume amino acids for vital physiological functions.

The author is particularly grateful to Drs V. R. Young and D. J. Millward for many stimulating discussions and for providing drafts of their recent manuscripts.

This work is a publication of the USDA/ARS Children's Nutrition Research Center, Department of Pediatrics, Baylor College of Medicine and Texas Children's Hospital, Houston, TX. This project has been funded in part with federal funds from the US Department of Agriculture, Agricultural Research Service under Cooperative Agreement number $58-7 \mathrm{MN} 1-6-100$. The contents of this publication do not necessarily reflect the views or policies of the US Department of Agriculture, nor does mention of trade names, commercial products, or organizations imply endorsement by the US Government.

\section{REFERENCES}

Agricultural Research Council (1981). The Nutrient Requirements of Pigs. Slough: Commonwealth Agricultural Burcaux.

Alqvist. S. E. G. (1951). Metabolic relationships among amino acids studied with isotopic nitrogen Acta Chemica Scandinarica 5, 1046-1064.

Beaton, G. H. \& Chery, A. (1988). Protein requirements of infants, a reexamination of concepts and approaches. American Journal of Clinical Nutrition 48, 1351-1361.

de Lange, C. F. M., Sauer, W. C., Mosethin, R. \& Souffrant, W. B. (1989a). The effect of feeding dilferent protein-free diets on the recovery and amino acid composition of endogenous protein collected from the distal ileum and feces in pigs. Journal of Animal Science 67, 746-754.

de Lange, C. F. M., Sauer. W. C., Mosethin. R. \& Souffrant, W. B. (1989b). The effect of protein status of the pig on the recovery and amino acid composition of endogenous protein in digesta collected from the distal ileum. Journal of Animal Science 67, 755-762.

de Lange. C. F. M. Souffrant, W. B. \& Sauer, W. C. (1990). Real ileal and amino acid digestibilities in feedstuffs for growing pigs as determined with the ${ }^{15} \mathrm{~N}$-isotope dilution technique. Journal of Animal Science 68, $409-418$.

Fomon, S. J.. Ziegler, E. E., Thomas. L. N. \& Filer, L. J. Jr (1971). Protein requirements of normal tnfants between 8 and 56 days of age. In Metabolic Processes in the Foetus and Newborn Infam, pp. 144-162|J. H. Jonxis. H. K. Visser and J. A. Troelstra, editors]. Leiden: Stenfert Kroese.

Food and Agricultural Organization/World Health Organization/United Nations University (1985). Energy and Prorein Requirements. Technical Report Series no. 724. Geneva: WHO.

Fuller, M. F. Cadenhead, A., Mollison. G. \& Seve, B. (1987). Effects of amount and quality of dietary protein on nitrogen metabolism and heat production in growing pigs. British Journal of Nutrition 58, 277-285.

Fuller, M. F. McWilliam, R.. Wang, T. C. \& Giles. L. R. (1989). The optimum dietary amino acid pattern for growing pigs 2. Requirements for maintenance and for tissue protein accretion. British Journal of Nutrition 62, 255-267.

Fuller, M. F. \& Wang, T. C. (1988). Amino acid requirements of the growing pig. In Manipulating Pig Production, pp. 97-111 [G. L. Barnett. E. S. Batterham, G. N. Cronin, C. Hansen. P. H. Hemsworth, D. P. Hennessy. P. E. Hughes, N. E. Johnston and R. H. King, editors]. Werribee, Australia: Australian Pig Sciences Association.

Golden, M. . Wateriow, J. C. \& Picou, D. (1977). The relationship between dietary intake, weight change nitrogen excretion and protein turnover in man. American Journal of Clinical Nuturition 30. 1345-13.88. 
Hovell, F. D. DeB., Ørskov. E. R., Kyle. D. J. \& MacL.eod, N. A. (1987). Undernutrition in sheep. Nitrogen repletion by $\mathrm{N}$-depleted sheep. British Journal of Nutrition $57,77-88$.

Jackson. A. A. \& Golden. M. H. N. (1980). ${ }^{15} \mathrm{~N}$-glycine metabolism in normal man. the metabolic a-amino nitrogen pool. Journal of Clinical Science 58, 517- 522 .

Low. A. G. (1980). Nutrient absorption in the pig. Journal of the Science of Food and Agriculture 31, $1087-1130$

Mason. V. C. \& Palmer, R. M. (1973). The influence of bacterial activity in the alimentary canal of rats on faecal nitrogen excretion. Acta Agricultura Scandinavica 23, 141-150.

Matthews, D. E., Conway, J. E., Young, V. R. \& Bier. D. M. (1981). Glycine nitrogen metabolism in man. Metabolism 30, 886-893.

Millward, D. J., Jackson. A. A. Price, G. \& Rivers. J. P. W. (1989). Human amino acid requirements, current dilemmas and uncertainties. Nutrition Reviews and Letters 2, 109-132.

Millward, D. J.. Price, G. M.. Pacy, P. J. H. \& Halliday, D. (1990). Maintenance protein requirements: the need for conceptual re-evaluation. Proceedings of the Nutrition Society 49, 473-487.

Millward, D. J. \& Rivers, J. P. W. (1988). The nutritional role of indispensable amino acids and the metabolic basis for their requirements. European Journal of Clinical Nutrition 42, 367-393.

Recds, P. J. (1987). Nitrogen metabolism and protein requirements. In Comparative Nutrition, pp. 55-72 [K. L. Blaxter and 1. MacDonald, editors]. London: John Libbey and Son.

Reeds, P. J. (1988). Milk proteins and tissue nitrogen equilibrium. In Milk Proteins, pp. 37-48 [C. A. Barth and E. Schlimme, editors]. New York: Springer Verlag.

Rennie, M. J., Babij, P., Taylor, P. M., Hundal. H. S., MacLennan. P., Watt. P. W.. Jepson, M. M. \& Millward, D. J. (1986). Characteristics of a glutamine carrier in skeletal muscle have important consequences for nitrogen loss in injury, infection and chronic disease. Lancet ii, 1008-1012.

Rerat, A.. Vaissade, P. \& Vaugelade, P. (1988). Quantitative measurement of endogenous amino acid absorption in unanacsthetised pigs. Archives of Animal Nutrition 6. 463-479.

Widdowson, E. M., Southgate. D. A. T. \& Hey, E. N. (1979). Body composition of the fetus and infant. In Nutrition and Metabolism of the fetus and infant, pp. 169-177 [H. K. A. Visser, editor]. The Hague: Martinus Nijhoff.

Yoshida. A. \& Moritoki. K. (1974). Nitrogen sparing action of methione and threonine in rats receiving a protein-free diet. Nutrition Reports International 9, 159-168.

Young, V. R. (1987). Kinetics of human amino acid metabolism. Nutritional implications and some lessons. American Journal of Clinical Nutrition 46, 709-725.

Young, V. R., Bier. D. M. \& Pellett. P. L. (1989). A theorctical basis for increasing current estimates of the amino acids requirements in adult man, with experimental support. American Journal of Clinical Nutrition 50, 80-92.

Young, V. R. \& Pellett, P. L. (1988). How to evaluate dictary protein. In Milk Proteins, pp. 7-36 [C. A. Barth and E. Schlimme, cditors]. New York: Springer Verlag. 